Images in...

\title{
Barium aspiration
}

\author{
Hameem I Kawsar, ${ }^{1}$ Jamila Shahnewaz, ${ }^{2}$ Basma Ricaurte, ${ }^{1}$ Hamed A Daw ${ }^{2}$ \\ ${ }^{1}$ Fairview Hospital, Cleveland, Ohio, USA; \\ ${ }^{2}$ Cleveland Clinic Cancer Center, Cleveland, Ohio, USA
}

Correspondence to Hamed A Daw, hdaw2000@yahoo.com

\section{DESCRIPTION}

A 75-year-old man with known chronic obstructive pulmonary disease and oral cancer, managed with surgery and radiotherapy 15 years ago, developed progressive dysphagia over the prior years. Because of postprandial abdominal pain for the previous 6 weeks, a barium swallow was performed elsewhere. During the procedure, he aspirated barium and developed dyspnoea and hypoxia. He was intubated and treated with antibiotics and then discharged. Six days later, he came to our hospital with increasing cough, fever and hypoxia, manifesting diminished breath sounds with bilateral crackles and ronchi. Chest roentgenogram showed opaque material in both lower lobes, right greater than left, consistent with barium aspiration. He was treated with bronchodilator, oxygen inhalation and appropriate antibiotics. Patients with oropharyngeal diseases are at higher risk of aspiration. Barium, although inert, is known to cause aspiration pneumonitis. ${ }^{1}$ In severe cases, barium aspiration is reported to cause death, especially in older patients. ${ }^{2} 3$

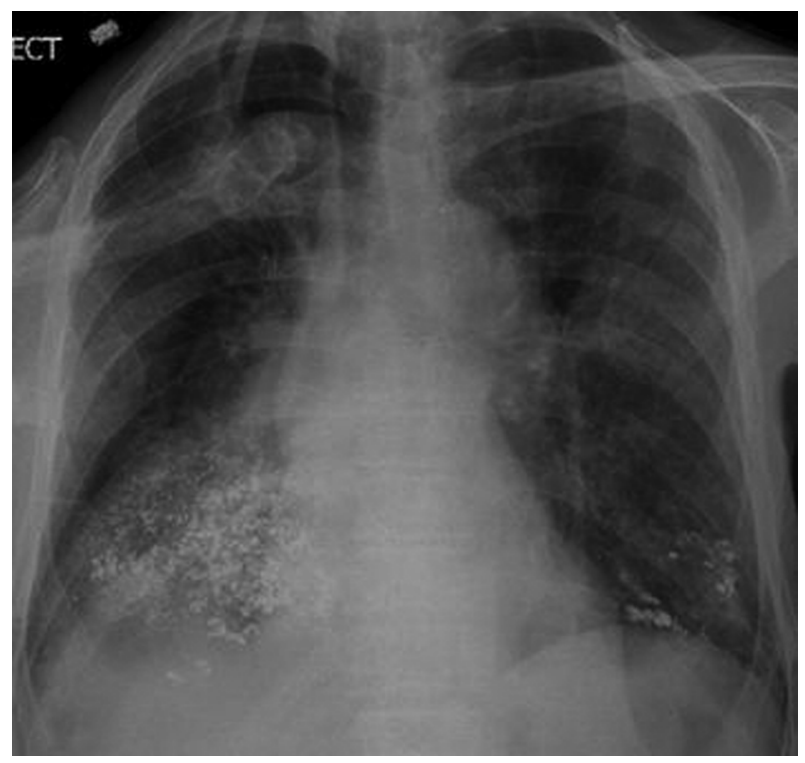

Figure 1 Chest x-ray, posteroanterior view.

\section{Learning points}

- Patients with oropharyngeal diseases are at higher risk of aspiration during oral contrast studies.

- Modified barium swallow evaluation may reduce the chance of aspiration.

Competing interests None.

Patient consent Obtained.

\section{REFERENCES}

1. Pracy JP, Montgomery PQ, Reading N. Acute pneumonitis caused by low density barium sulphate aspiration. J Laryngol Otol 1993;107:347-8.

2. Fruchter 0, Dragu R. Images in clinical medicine. A deadly examination. N Engl J Med 2003;348:1016.

3. Albeldawi M, Makkar R. Images in clinical medicine. Barium aspiration. N Engl J Med 2012;366:1038.

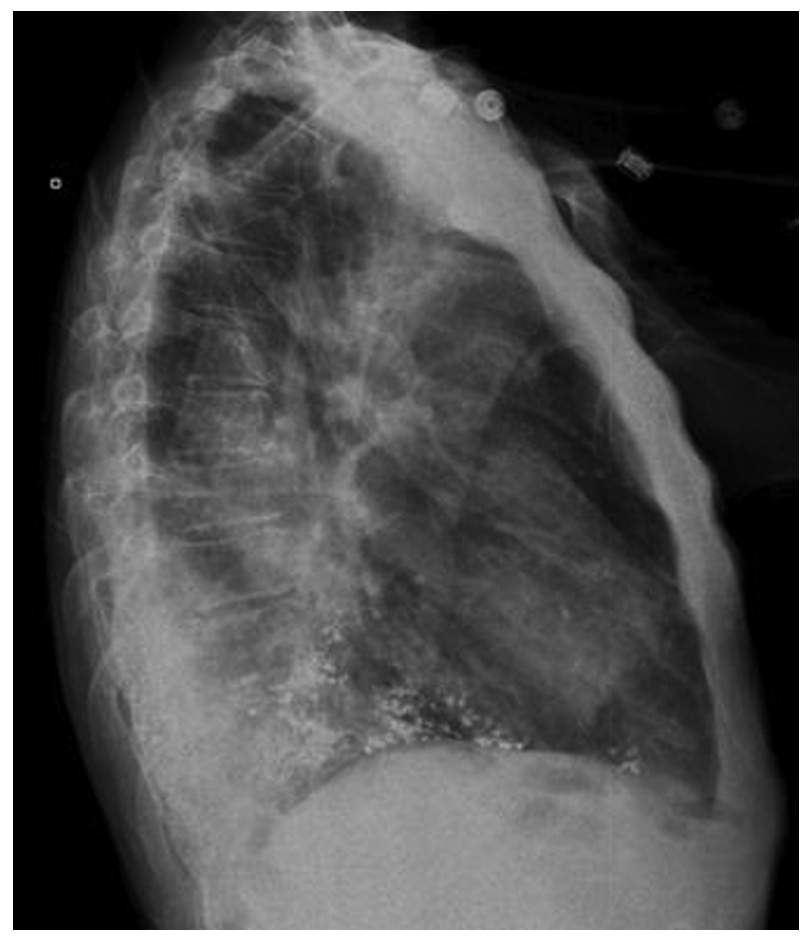

Figure 2 Chest x-ray, lateral view. 


\section{BMJ Case Reports}

This pdf has been created automatically from the final edited text and images.

Copyright 2012 BMJ Publishing Group. All rights reserved. For permission to reuse any of this content visit http://group.bmj.com/group/rights-licensing/permissions.

BMJ Case Report Fellows may re-use this article for personal use and teaching without any further permission.

Please cite this article as follows (you will need to access the article online to obtain the date of publication).

Kawsar HI, Shahnewaz J, Ricaurte B, Daw HA. Barium aspiration. BMJ Case Reports 2012;10.1136/bcr.02.2012.5891, Published XXX

Become a Fellow of BMJ Case Reports today and you can:

- Submit as many cases as you like

- Enjoy fast sympathetic peer review and rapid publication of accepted articles

- Access all the published articles

- Re-use any of the published material for personal use and teaching without further permission

For information on Institutional Fellowships contact consortiasales@bmjgroup.com

Visit casereports.bmj.com for more articles like this and to become a Fellow

Keep up to date with all published cases by signing up for an alert (all we need is your email address) http://casereports.bmj.com/cgi/alerts/etoc 